\title{
The Policy on Children of the ICC Office of the Prosecutor: Toward greater accountability for Crimes against and affecting Children
}

\section{Diane Marie Amann}

Emily \& Ernest Woodruff Chair in International Law and Faculty Co-Director of the Dean Rusk International Law Center University of Georgia School of Law, amann@uga.edu

University of Georgia School of Law

Research Paper Series

Paper No. 2020-09

Dean Rusk International Law Center

Research Paper Series

Paper No. 2020-03

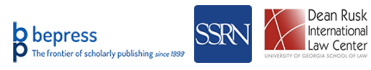

\section{Repository Citation}

Diane Marie Amann, The Policy on Children of the ICC Office of the Prosecutor: Toward greater accountability for Crimes against and affecting Children Int'I Rev. Red Cross (2020),

Available at: https://digitalcommons.law.uga.edu/fac_artchop/1322

This Article is brought to you for free and open access by the Faculty Scholarship at Digital Commons @ University of Georgia School of Law. It has been accepted for inclusion in Scholarly Works by an authorized administrator of Digital Commons @ University of Georgia School of Law. Please share how you have benefited from this access For more information, please contact tstriepe@uga.edu. 


\title{
The Policy on Children of the ICC Office of the Prosecutor: Toward greater accountability for Crimes against and affecting Children
}

\section{Diane Marie Amann}

Diane Marie Amann is Emily \& Ernest Woodruff Chair in International Law and Faculty CoDirector of the Dean Rusk International Law Center, University of Georgia School of Law. She has served since 2012 as the International Criminal Court Prosecutor's Special Adviser on Children in and affected by Armed Conflict."

[Note: This is the author's version of the article published online 21 February 2020 in the International Review of the Red Cross. The published version is available to Cambridge Core subscribers at the First View page; once it appears in print, in a special issue on "Children and War," it will be freely accessible at the Review website.]

\begin{abstract}
The Policy on Children published by the International Criminal Court Office of the Prosecutor in 2016 represents a significant step toward accountability for harms to children in armed conflict and similar extreme violence. This article describes the process that led to the Policy and outlines the Policy's contents. It then surveys relevant ICC practice and related developments, concluding that despite some salutary efforts, much remains to be done to recognize, prevent and punish the spectrum of conflicted-related crimes against or affecting children.
\end{abstract}

Keywords: children, child soldiers, crimes against humanity, genocide, International Criminal Court, war crimes.

\footnotetext{
* As Special Adviser, she assisted in the research, drafting and implementation of the Policy discussed in this article; however, the article itself is written solely in her personal capacity.
} 
Children have become the unwilling emblems of armed conflict and extreme violence. Searing proofs of this claim surface almost daily in news stories, aid workers' alerts and rights groups' dispatches. Unforgettable was the 2015 photograph of a war-refugee whose three-year-old body had washed up, face down, onto a Turkish beach. ${ }^{1}$ Yet it was by no means unique. The innumerable images that appeared in succeeding years included toddlers in trucks bound for camps, a five year old pulled from Aleppo rubble, a South Sudanese small soldier wedged in line between much taller adult infantrymen, and a seven year old reduced to skin and bones on account of Yemen's conflict-fueled famine. ${ }^{2}$ Putting to one side the ethical concerns surrounding the publication of such images, ${ }^{3}$ these depictions underscore the need to continue to press for strategies both to combat harms against children and to bring the persons responsible to justice.

Several ongoing initiatives merit particular attention. The UN Office of the Special Representative of the Secretary-General for Children and Armed Conflict monitors what are known as the Six Grave Violations. Derived from the Special Representative's analysis of UN Security Council resolutions as well as international humanitarian, human rights and

${ }^{1}$ Helena Smith, "Shocking Images of Drowned Syrian Boy Show Tragic Plight of Refugees”, Guardian, 2 September 2015, available at: https://www.theguardian.com/world/2015/sep/02/shocking-image-of-drowned-syrian-boy-showstragic-plight-of-refugees. All Internet sources cited in this article last accessed 22 December 2019.

2 See Richard Hall, “Children of Foreign Isis Fighters in Syria Are 'among World's Most Vulnerable' and Should Be Brought Home, Says UN”, Independent, 22 May 2019, available at: https://www.independent.co.uk/news/world/middle-east/isis-children-shamima-begum-syria-foreign-islamic-stateun-a8925601.html; Jonathan Kolieb, “When Soldiers Go Back to Being Children”, Foreign Policy, 12 December 2018, available at: https://foreignpolicy.com/2018/12/12/when-soldiers-go-back-to-being-children/; Kevin Ponniah, "Syrian Conflict: Why Are Children So Badly Affected in Aleppo?", BBC News, 26 September 2016, available at: https://www.bbc.com/news/world-middle-east-37472975; Declan Walsh, "Yemen Girl Who Turned World's Eyes to Famine Is Dead", New York Times, 1 November 2018, available at: https://www.nytimes.com/2018/11/01/world/middleeast/yemen-starvation-amal-hussain.html.

${ }^{3}$ See, e.g., Nancy Lipkin Stein and Alison Dundes Renteln (eds), Images and Human Rights: Local and Global Perspectives, Cambridge Scholars Publishing, Newcastle upon Tyne, 2017; Heide Fehrenbach and Davide Rodogno, “'A Horrific Photo of a Drowned Syrian Child': Humanitarian Photography and NGO Media Strategies in Historical Perspective", International Review of the Red Cross, No. 900, 2016, pp. 1121-1155. Discussion of this important issue is beyond the scope of this article. 
international criminal law, the six violations are: recruitment and use of children; killing or maiming of children; sexual violence against children; attacks against schools or hospitals; abduction of children; and denial of humanitarian access. ${ }^{4}$ UNICEF and many other UN entities complement the Special Representative's efforts. Meanwhile, groups forming the Global Coalition to Protect Education from Attack have secured 101 States' endorsements of a Safe Schools Declaration. ${ }^{5}$ Eighty-nine States have endorsed the Vancouver Principles on Peacekeeping and the Prevention of the Recruitment and Use of Child Soldiers. ${ }^{6}$ These and other soft-law instruments amplify obligations that States assumed when they joined the 1989 Convention on the Rights of the Child or a handful of child-related treaties, compiled in the International Committee of the Red Cross database. ${ }^{7}$

Taken together, such initiatives indicate normative support for child protection; and yet, they lack teeth. Some depend largely on endorsers' good faith, or on whatever deterrence may lie in the power to name and shame wrongdoers. Others simply hope that each State party will incorporate articulated norms into its internal law enforcement system. The presence of an international jurisdiction that is able, and willing, to prosecute conflict-linked crimes against children is thus essential to the struggle against commission of such crimes.

${ }^{4}$ Office of the Special Representative of the Secretary-General for Children and Armed Conflict, The Six Grave Violations Against Children During Armed Conflict: The Legal Foundation, October 2009/updated November 2013, p. $9, \quad$ available $\quad$ at: $\quad$ https://childrenandarmedconflict.un.org/publications/WorkingPaper1_SixGraveViolationsLegalFoundation.pdf.

${ }^{5}$ See Global Coalition to Protect Education from Attack, available at: http://protectingeducation.org/ (including text of the 2014 declaration, formally named the Guidelines for Protecting Schools and Universities from Military Use during Armed Conflict, as well as list of endorsers). Error! Main Document Only.See also Ashley Ferrelli, "Military Use of Educational Facilities during Armed Conflict: An Evaluation of the Guidelines for Protecting Schools and Universities from Military Use during Armed Conflict as an Effective Solution”, Georgia Journal of International and Comparative Law, Vol. 44, No. 2, 2016, pp. 339-367.

${ }^{6}$ See Vancouver Principles, available at: https://www.vancouverprinciples.com/ (including text of the principles and list of endorsers).

${ }^{7}$ International Committee of the Red Cross, "Children”, available at: https://www.icrc.org/en/war-and-law/protectedpersons/children (listing relevant treaties and customary international law). See Convention on the Rights of the Child, 1577 UNTS 3, 20 November 1989 (entered into force 2 September 1990) (Child Rights Convention). All UN member States have ratified this treaty except for the United States, which also is an ICC nonparty State. 
Tribunals that served this role in recent decades include the Special Court for Sierra Leone, which enunciated the customary international law status of the ban on child-soldiering and subsequently imprisoned a former head of State for violating that ban, ${ }^{8}$ and the International Criminal Court, whose first case centered entirely on a militia commander's culpability for the war crimes of conscripting, enlisting and using in hostilities children under fifteen. ${ }^{9}$ Although they broke ground by calling leaders to account for child combatancy, these cases failed to identify, prosecute or punish the full range of international crimes that children endure amid armed conflict and similar extreme violence.

Following her election as the ICC's second Prosecutor, Fatou Bensouda announced plans for a broader approach in an important 2012 speech. "Our focus," she said, "should shift from 'children with arms' to 'children who are affected by the arms' in the context of the crime of enlisting and conscripting child soldiers". ${ }^{10}$ To that end, Bensouda appointed the Prosecutor's first Special Adviser on Children in and affected by Armed Conflict, consistent with a mandate in the ICC's Rome Statute; ${ }^{11}$ listed, as one of her office's six strategic goals, "particular attention

${ }^{8}$ SCSL, Prosecutor v. Taylor, Appeals Judgment, Case No. SCSL-03-01-A, 26 September 2013; SCSL, Prosecutor v. Norman - Decision on Preliminary Motion Based on Lack of Jurisdiction (Child Recruitment), Case No. SCSL2004-14-AR72(E), 31 May 2004. Both judgments available at: http://www.rscsl.org/. On the work of this court, see Cecile Aptel, "Unpunished Crimes: The Special Court for Sierra Leone and Children”, in Charles Jalloh (ed.), The Sierra Leone Special Court and Its Legacy, Cambridge University Press, New York, 2014, p. 340.

${ }^{9}$ ICC, Prosecutor v. Lubanga, Judgment on the appeal of Mr Thomas Lubanga Dyilo against his conviction, ICC01/04-01/06 A 5, 1 December 2014. Unless otherwise noted, all ICC documents cited in this article are available at: https://www.icc-cpi.int/. For a discussion of Lubanga, see, e.g., Diane Marie Amann, "Children and the First Verdict of the International Criminal Court", Washington University Global Studies Law Review, Vol. 12, No. 3, 2013, pp. $411-432$.

${ }^{10}$ Fatou Bensouda, "The Incidence of the Female Child Soldier and the International Criminal Court", keynote speech before the Eng Aja Eze Foundation in New York, 4 June 2012, available at: http://cpcjalliance.org/international-dayafrican-child/. Notably, that same year saw the issuance by the Extraordinary Chambers in the Courts of Cambodia of a judgment that did discuss a range of children's experiences - a fact seldom remarked, perhaps because the counts of conviction were not explicitly framed as crimes against or affecting children. See ECCC, Case No. 001/18-072007/ECCC/TC (Prosecutor v. Kaing Guek Eav alias Duch), Appeal Judgement, 3 February 2012, available at: https://www.eccc.gov.kh/en/.

${ }^{11}$ Rome Statute of the International Criminal Court, UN Doc. A/CONF.183/9, 17 July 1998 (entered into force 1 July 
to ... crimes against children"; ${ }^{12}$ and initiated work on a policy paper on the subject. The result was the ICC Office of the Prosecutor Policy on Children, published in 2016 in English, and in Arabic, French, Spanish and Swahili translations. ${ }^{13}$

This article focuses on that Policy. It first lays out the Policy's contents, then discusses relevant ICC practice and related developments. The article concludes that although the Policy is an important component of ongoing efforts, much remains to be done to recognize, prevent and punish the spectrum of conflicted-related crimes against children.

\section{[Heading level 1]ICC Office of the Prosecutor Policy on Children}

The Policy on Children emerged out of research, drafting and editing undertaken by a working group composed of staff in various Office of the Prosecutor sub-units, along with the Special Adviser on Children in and affected by Armed Conflict. Supplementing the working group's internal process were numerous external meetings: gatherings of academic experts and practitioners at Leiden Law School in the Netherlands and at the Dean Rusk International Law Center, University of Georgia School of Law, in the United States; a consultation at the ICC premises with a global array of representatives of civil society organizations; and dialogues, in

2002) (Rome Statute), Art. 42(9) (“The Prosecutor shall appoint advisers with legal expertise on specific issues, including, but not limited to, sexual and gender violence and violence against children".); ICC, "ICC Prosecutor Fatou Bensouda appoints Patricia Sellers, Leila Sadat and Diane Marie Amann as Special Advisers” (12 December 2012).

12 ICC Office of the Prosecutor, Strategic Plan June 2012-2015 (11 Oct. 2013), p. 17, para. 32(3).

${ }^{13}$ ICC Office of the Prosecutor, Policy on Children (November 2016) (Policy on Children, or, simply, Policy). This article cites only the English version; all five versions are available at: https://www.icc-

cpi.int/Pages/item.aspx?name=161115-otp-policy-children. Published as a paperback booklet, this document was the sixth in a series that the Office had issued. Preceding it were "policy papers" dating to 2007 and covering issues including victims' participation, preliminary examinations and case selection. See ICC Office of the Prosecutor, "Policies and Strategies"; see also note 18. The Office has announced work on at least one other such policy initiative. See ICC, “The ICC Office of the Prosecutor and UNESCO Sign Letter of Intent to Strengthen Cooperation on the Protection of Cultural Heritage", 6 November 2017. For an analysis of papers that predated the Policy on Children, see Lovisa Bådagård and Mark Klamberg, "The Gatekeeper of the ICC: Prosecutorial Strategies for Selecting Situations and Cases at the International Criminal Court”, Georgetown Journal of International Law, Vol. 48, No. 3, 2017, pp. 639-733. 
Canada, Colombia, the Democratic Republic of the Congo, the Netherlands, Qatar, Sierra Leone and Somalia, with young people, many of whom had lived in conflict zones. ${ }^{14}$ The Policy's public launch took place in November 2016, at an event in The Hague that featured speeches by Prosecutor Bensouda, Zeid Ra'ad Al Hussein, then the UN High Commissioner for Human Rights, and General Roméo Dallaire, founder of the Roméo Dallaire Child Soldiers Initiative. ${ }^{15}$ Published in booklet form and spanning forty-four dense pages, the Policy on Children highlighted the concern for children that is apparent in the Rome Statute's preamble, enumeration of crimes, and other provisions, and in instruments like the ICC Rules of Procedure and Evidence and Elements of Crimes. ${ }^{16}$ Observing "that most crimes under the Statute affect children in various ways", the Policy promised "particular attention" by the Office of the Prosecutor "both to the commission of crimes against or affecting children, and to its own interaction with children". ${ }^{17}$ Its elaboration of that promise adhered to the format that the office had adopted in its Policy Paper on Sexual and Gender-Based Crimes, issued two years earlier. ${ }^{18}$ An Executive Summary thus opened the Policy on Children, preceding chapters entitled "Introduction", "General Policy" and "The Regulatory Framework". Together, those three chapters synthesized legal instruments, doctrines and jurisprudence pertaining to harms that the Rome Statute authorizes the ICC to prosecute and punish - harms referred throughout the Policy on Children as "crimes against or affecting children". Then followed a final part of a more operational nature, composed of six chapters on "Preliminary Examinations", "Investigations", "Prosecutions", "Cooperation and External Relations", "Institutional Development" and "Implementation". Each part will be discussed in turn.

\footnotetext{
${ }^{14}$ Policy on Children, pp. 10-11, paras. 13-14 and n. 22. ICC Office of the Prosecutor staffers leading this process were Shamila Batohi and Yayoi Yamaguchi, then the Senior and Associate Legal Advisers, respectively, and Gloria Atiba Davies, Head of the Gender and Children Unit.

${ }^{15}$ See ICC, "ICC Prosecutor, Fatou Bensouda, launches Policy on Children: 'We must strengthen our resolve to end impunity for atrocity crimes against and affecting children", 18 November 2016 (including videos of these and other speakers).

${ }^{16}$ Policy on Children, pp. 6-8, paras. 1-4.

${ }^{17}$ Ibid., p. 11, para. 15; ibid., p. 12, para. 17.

${ }^{18}$ ICC Office of the Prosecutor, Policy Paper on Sexual and Gender-Based Crimes (June 2014) (ICC OTP Policy Paper on Sexual and Gender-Based Crimes).
} 
[Heading level 2]Legal synthesis

Embedded in the Policy on Children is a synthesis of international and regional instruments, jurisprudence, advocacy reports and academic literature touching on children and armed conflict. These writings were relatively unconnected at the time that work on the Policy began. Broadbased treatment of the ICC and children appeared in commentaries issued soon after the 1998 adoption of the Rome Statute, ${ }^{19}$ yet it had narrowed somewhat over time. The phenomenon of child-soldiering did garner extensive attention in international humanitarian, human rights and criminal law circles, but almost to the exclusion of the many other ways that armed conflict and extreme violence affect children. Sexual violence also was discussed, and so too treatment of victims and witnesses; not infrequently, however, the needs of children merged into those of adults. ${ }^{20}$ Child rights literature, meanwhile, tended to center on compliance within national systems. Work on the Policy thus entailed, and helped to generate, new and comprehensive research. $^{21}$

As an initial matter, development of the Policy required determining the meaning of "child". The Rome Statute does not define the word, and while it authorizes ICC jurisdiction only if a person was at least eighteen at the time of the alleged crime, its child-soldiering

19 See, e.g., Antonio Cassese, Paola Gaeta and John R.W.D. Jones (eds), The Rome Statute of the International Criminal Court: A Commentary, Oxford, Oxford University Press, 2002; Otto Triffterer (ed.), Commentary on the Rome Statute of the International Criminal Court, 2d ed., Beck/Hart, London, 2008; Roy S. Lee (ed.), The International Criminal Court: The Making of the Rome Statute: Issues, Negotiations, Results, Kluwer Law International, The Hague, 1999.

${ }^{20}$ Cf. Diane Marie Amann, "The Post-Postcolonial Woman or Child", American University International Law Review, Vol. 30, No. 1, 2015, pp. 41-52, at p. 48 (criticizing “"womenandchildren"” conceptualizations and preferring analysis of "the many different hues of human experience").

${ }^{21}$ E.g., Linda A. Malone, "Maturing Justice: Integrating the Convention on the Rights of the Child into the Judgments and Processes of the International Criminal Court," Georgia Journal of International and Comparative Law, Vol. 43, No. 3, 2015, pp. 599-622, and other articles in this symposium issue. See also Diane Marie Amann, "Children”, in William A. Schabas (ed.), The Cambridge Companion to International Criminal Law, Cambridge University Press, Cambridge, 2016, p. 253. 
provisions apply only if the child recruited or used by an armed force is under fifteen. The Policy specified that "children" included "persons who have not yet attained the age of eighteen"; in so doing, it pointed not only the Statute's prosecution threshold, but also to the understanding that in the prohibition of forcible transfer as genocide, the term "children" connotes any person under the age of eighteen. ${ }^{22}$ The Policy construed the recruitment-or-use age of under fifteen not as a definition but rather as a statutory element that confers ICC jurisdiction over a specific war crime. $^{23}$

Having established what it means by "child", the Policy embraced what it labeled "a child-sensitive approach", to be applied in all the work of the Office of the Prosecutor, and grounded in the Child Rights Convention:

"This approach appreciates the child as an individual person and recognises that, in a given context, a child may be vulnerable, capable, or both. The child-sensitive approach requires staff to take into account these vulnerabilities and capabilities. This approach is based on respect for children's rights and is guided by the general principles of the 1989 Convention on the Rights of the Child: non-discrimination; the best interests of the child; the right to life, survival and development; and the right to express one's views and have them considered". 24

The use of "child-sensitive" rather than, say, "child-centred" reflected the balancing of children's and many others' interests that is inherent in the work of a prosecutor's office; indeed, the term “child-sensitive" was derived from 2005 UN guidelines on treatment of children who appear as victims or witnesses within a legal system. ${ }^{25}$

\footnotetext{
${ }^{22}$ Policy on Children, pp. 11-12, para. 16 (citing Rome Statute, Art. 26; ICC, Elements of Crimes, Art. 6(3)).
}

${ }^{23}$ Ibid., p. 20, para. 40 (observing, in accompanying note 51, that the same age appears in the 1977 Additional Protocols to the Geneva Conventions and the 1989 Child Rights Convention, but that it has been raised to eighteen in more recent treaties, including the 1990 African Convention on the Rights and Welfare of the Child, the 1999 International Labour Organization Convention No. 182 and a 2000 Optional Protocol to the Child Rights Convention). See Ahmed Al-Dawoody and Vanessa Murphy, "International Humanitarian Law, Islamic Law and the Protection of Children in Armed Conflict", International Review of the Red Cross, Vol.101 No.911 (forthcoming), p. 10 (examining recruitment ages in different legal systems).

24 Policy on Children, p. 13, para. 22.

${ }^{25}$ See ibid., p. 13, para. 22, n. 29 (quoting UN Guidelines on Justice in Matters involving Child Victims and Witnesses 
The Policy's explanation of the child-sensitive approach, moreover, effectively rejected a characterization often heard in discourses of international criminal law, international human rights law and international humanitarian law. To be specific, it moved away from what Professor Mark Drumbl has dubbed the notion of the child as "faultless passive victim". ${ }^{26}$ "Children may be victims", the Policy observed, then added: "they may be involved in the commission of crimes; they may witness the commission of crimes against others, including members of their own families; or they may be unable to receive an education or medical care due to the destruction of schools or hospitals". ${ }^{27}$ Furthermore, "children may be impacted differently by crimes based on their sex, gender, or other status or identities", the Policy said. ${ }^{28}$ These observations signaled a recognition, common in contemporary international child law, that children, like all human beings, are rights-bearing, multi-faceted individuals and at the same time members of multi-generational communities:

"Children, by the very fact of their youth, are frequently more vulnerable than other persons; at certain ages and in certain circumstances, they are dependent on others. Notwithstanding any vulnerability and dependence, children possess and are continuously developing their own capacities - capacities to act, to choose and to participate in activities and decisions that affect them. The Office will remain mindful, in all aspects of its work, of the evolving capacities of the child". ${ }^{29}$

The commitment to engage with children according to their capacities informed an integral component of the child-sensitive approach; to be specific, the two-step inquiry posited as a means to arrive at decisions in the best interests of the child:

- First, "assess the best interests of the child", considering "the views of the child and of

of Crime, para. 9(d) of Annex to ECOSOC Resolution 2005/20, available at: https://www.un.org/ecosoc/sites/www.un.org.ecosoc/files/documents/2005/resolution-2005-20.pdf).

${ }^{26}$ Mark A. Drumbl, Reimagining Child Soldiers in International Law and Policy, Oxford University Press, Oxford and New York, 2012, pp. 8-9.

27 Policy on Children, p. 12, para. 17.

28 Ibid., p. 12, para. 18.

${ }^{29}$ Ibid., p. 14, para. 25. See ibid., p. 7, para. 3 (describing generational concerns); ibid., p. 14, para. 24 (listing child rights). See also Child Rights Convention, Art. 5 (referring to child's evolving capacities). 
other relevant persons, and the child rights at issue" - plus "the child's specific situation", which may include pertinent, and likely intersecting, factors, such as age and maturity, ability or disability, gender or sexuality, status in an underrepresented group, and living circumstances; ${ }^{30}$ and

- Second, examine whether any other factors "require a balancing of various interests"; such factors may include "legal or operational issues", as well as conflicts between the interests of the child and those of parents or other parties to the decision. ${ }^{31}$

After setting out this synthetic framework for considering issues related to children, the Policy next identified crimes of special concern.

[Heading level 2]Enumeration of crimes against or affecting children

Almost all crimes within the ICC's jurisdiction affect children, the Policy on Children reiterated; focus was placed on crimes in the Rome Statute that expressly refer to children, and on several other "crimes directed specifically against children or those that disproportionately affect them". 32 The Policy thus emphasized the following crimes against or affecting children:

- Conscription, enlistment and use of children under the age of fifteen years to participate actively in hostilities, as war crimes in violation of the Rome Statute, Arts. 8(2)(b)(xxvi), $8(2)(\mathrm{e})(\mathrm{vii})$;

- Forcible transfer of children and prevention of birth, as acts of genocide in violation of the Rome Statute, Arts. 6(d), 6(e);

- Trafficking of children as a form of enslavement constituting a crime against humanity in violation of Rome Statute, Arts. 7(1)(c), 7(2)(c);

- Attacks on buildings dedicated to education and health care, as war crimes in violation of the Rome Statute, Arts. 8(2)(b)(ix), 8(2)(e)(iv);

- Torture and related war crimes and crimes against humanity, in violation of the Rome

\footnotetext{
30 Policy on Children, p. 16, paras. 29-31; see also ibid., pp. 18-19, para. 37.

31 Ibid., p. 16, para. 29; ibid., p. 17, para. 32.

32 Ibid., p. 19, para. 38; see also text accompanying note 17.
} 
Statute, Arts. 7(1)(f), 7(1)(k), 8(2)(a)(ii), 8(2)(a)(iii), 8(2)(c)(ii);

- Persecution as a crime against humanity, in violation of the Rome Statute, Art. 7(1)(h); and,

- Sexual and gender-based violence as war crimes and crimes against humanity, in violation of the Rome Statute, Arts. 7(1)(g), 8(2)(b)(xxii), 8(2)(e)(vi). ${ }^{33}$

Overlaps between the Policy's Rome Statute listing and the United Nations' Six Grave Violations are evident. Both enumerations evince concern, for example, about child soldiers, attacks on schools or hospitals, and sexual violence. To be precise, the Policy spoke not of "sexual violence" but rather of "sexual and gender-based crimes", a phrasing that paid heed to the fact that boys as well as girls may be victims of crimes "because of their sex and/or socially constructed gender roles", and that such crimes "are not always manifested as a form of sexual violence". ${ }^{34}$ One notable addition in the Policy's listing of crimes against or affecting children is persecution; the Policy makes clear that "acts targeting children on the basis of age or birth may be charged as persecution on 'other grounds", and "that children may also be persecuted on intersecting grounds, such as ethnicity, religion and gender". ${ }^{35}$ Another addition is torture, which is excluded from the UN list albeit sometimes cited by UN officials as an aspect of listed violations like sexual violence. ${ }^{36}$ The Policy further added child trafficking and forcible transfer of children, provided that those acts meet the requisite contextual elements of a crime against humanity or genocide. The inclusion of these two categories of international crimes underlines the Policy's wider scope. As a formal matter, the UN Special Representative's mandate is limited to armed conflict. ${ }^{37}$ But the Rome Statute, upon which the Policy is founded, additionally

\footnotetext{
${ }^{33}$ Policy on Children, pp. 19-25, paras. 39-52.

${ }^{34}$ Ibid., p. 12, para. 19 and n. 28 (citing ICC OTP Policy Paper on Sexual and Gender-Based Crimes, p. 12, para. 16).

35 Ibid., p. 24, para. 51 (quoting Rome Statute, Art. 7(1)(h)).

${ }^{36}$ See Statement by Virginia Gamba, Special Representative of the Secretary-General for Children and Armed Conflict, "Briefing to the Security Council on the situation of children in Syria (humanitarian)" (27 July 2018), available at: https://childrenandarmedconflict.un.org/srsgs-briefing-to-the-security-council-on-the-situation-ofchildren-in-syria/ (stating with regard to the ongoing civil war in Syria, "[r]ape has been used as a means of torture, especially while children were deprived of their liberty").

${ }^{37}$ See "The rights of the child", UNGA Res. 51/77, 20 February 1997, p. 7, para. 35.
} 
confers jurisdiction over widespread or systematic attacks against civilian populations, in the case of crimes against humanity, and even over peacetime, in the case of genocide. ${ }^{38}$

[Heading level 2]Operational aspects

The legal framework concerning crimes against or affecting children having been set out, the balance of the Policy considered operational aspects in all the activities of the Office of the Prosecutor. These included preliminary examination, investigation, charging and prosecutions, cooperation and external relations, institutional development and, finally, implementation.

Envisaged regarding the latter aspects were more training, greater cooperation with partners and further dissemination of the Policy, "in a format that children can understand". 39

Animating this part was the child-sensitive approach, amplified by the office's commitment to "strive to ensure that its activities do no harm to the children with whom it interacts, particularly victims and witnesses". ${ }^{40}$ In fulfillment of earlier statements on children's capacities, the Policy stated "that children are capable of giving credible evidence"; furthermore, that "the views of children and their parents or caregivers on matters affecting them" would be sought out and considered. ${ }^{41}$ Detailed procedures, including video- and audio-recording, were specified for staff contacts with children. ${ }^{42}$

Of particular note was the Policy's pledge to "make full use of the regulatory framework to address the various ways that children are affected by crimes within the jurisdiction of the Court", with the aim of "strengthening the accountability for such crimes, thereby contributing to their prevention, and also to the development of jurisprudence". ${ }^{43}$ Naming again the Rome

\footnotetext{
${ }^{38}$ See Rome Statute, Art. 6 (setting out as the sole chapeau element "intent to destroy, in whole or in part, a national, ethnical, racial or religious group"); ibid., Art. 7(1) (detailing the contextual elements of crimes against humanity). "Peacetime" is used advisedly, given the violent essence of genocide.

${ }^{39}$ Policy on Children, p. 43, para. 116; see ibid., pp. 41-44, paras. 108-125.

40 Ibid., p. 17 , para. 33.

${ }^{41}$ Ibid., p. 29, para. 68; ibid., p. 29, para. 66.

${ }^{42}$ See ibid., pp. 28-33, paras. 63-82; ibid., pp. 35-37, paras. 89-97.

${ }^{43}$ Ibid., pp. 33-34, para. 84; see ibid., p. 38, para. 100 (detailing how this approach affects the presentation of evidence).
} 
Statute crimes against or affecting children that it already had listed, the Policy stated: "In order to capture the totality of the violence perpetrated against children, and to highlight the unique experiences of children, the Office will consider appropriate charges wherever the evidence permits". ${ }^{44}$ This consideration was to extend to the end of trial; should the accused be convicted, "crimes against or affecting children should be seen as particularly grave for the purpose of sentencing ... taking into account the immediate and long-term harms caused to children, their families and communities". ${ }^{45}$ In sum, the Policy's commitment to a full accounting for crimes against or affecting children bore echo to Prosecutor Bensouda's 2012 agenda-setting speech, ${ }^{46}$ and furthermore established a framework for ICC practice.

\section{[Heading level 1] ICC practice and related developments}

The agenda of broadening ICC's treatment of children's experiences beyond those related to recruitment or used in armed groups has surfaced not only in strategic documents like the Office of the Prosecutor Policy on Children, but also in ICC practice.

Following the surrender in 2013 of a long-time fugitive Congolese rebel leader, the ICC Office of the Prosecutor amended the original indictment to include war crimes charges that the accused was responsible not only for the recruitment and use of children, but also for acts of rape and sexual slavery, committed by subordinates in his militia, against children under fifteen in the same militia. ${ }^{47}$ An interlocutory judgment by the ICC Appeals Chamber sustained the new charges, setting a precedent that promises to expand the scope of protection against sexual and gender-based crimes not only for underaged children, but also for youths and adults victimized

\footnotetext{
${ }^{44}$ Ibid., p. 34, para. 88.

${ }^{45}$ Ibid., p. 39, paras. 102-103. Similar phrasing described the determination of gravity at the preliminary examination stage. Ibid., p. 26, para. 57. Likewise, any prosecutorial submissions on reparations ought to "contribute to the best interests of children". Ibid., p. 40, para. 106.

${ }^{46}$ See note 10 and accompanying text.

47 See ICC, Prosecutor v. Ntaganda, Decision Pursuant to Article 61(7)(a) and (b) of the Rome Statute on the Charges of the Prosecutor Against Bosco Ntaganda, ICC-01/04-02/06, ICC Pre-Trial Chamber II, 9 June 2014, paras. $36,74$.
} 
by or within armed groups, with which they have become associated. ${ }^{48}$ A Trial Chamber convicted the accused of those and other charges in July 2019, and subsequently sentenced him to thirty years' imprisonment. ${ }^{49}$ That same month, an Appeals Chamber confirmed a US $\$ 10$ million reparations award against another Congolese militia leader, the defendant in the ICC's first case, for hundreds of victims, identified as "children under the age of fifteen years who were conscripted or enlisted into the FPLC, or used to participate actively in hostilities, as well as to indirect victims - including family members of those children". ${ }^{50}$ Meanwhile, the victimization in Myanmar of Rohingya children and their families formed the core of a new ICC investigation, authorized in November 2019 following a request by the prosecutor. Recounting the allegations on which it had based its authorization decision, the Pre-Trial Chamber wrote with respect to Myanmar: "Victims' representations also mention that children were often targeted and killed, including small children who were thrown into water or fire to die". 51

Another aspect of the 2016 Policy on Children - the fact that amid armed conflict children "may be involved in the commission of crimes" - played out in the three-year trial on multiple charges, including several crimes against or affecting children, of a Ugandan

${ }^{48}$ ICC, Prosecutor v. Ntaganda, Judgment on the appeal of Mr Ntaganda against the "Second decision on the Defence's challenge to the jurisdiction of the Court in respect of Counts 6 and 9", ICC-01/04-02/06-1962, 15 June 2017. For a meticulous analysis of this decision, see Patricia Viseur Sellers, "Ntaganda: Re-Alignment of a Paradigm", in Fausto Pocar (ed.), The Additional Protocols 40 Years Later: New Conflicts, New Actors, New Perspectives, International Institute of Humanitarian Law/Franco Angeli, Milan, 2018, p. 116, http://iihl.org/wpcontent/uploads/2018/07/The-Additional-Protocols-40-Years-Later-New-Conflicts-New-Actors-NewPerspectives_2.pdf.

${ }^{49}$ ICC, Prosecutor v. Ntaganda, Judgment, ICC-01/04-02/06-2359, Trial Chamber VI, 8 July 2019; ICC, Prosecutor v. Ntaganda, Sentencing Judgment, ICC-01/04-02/06-2442, Trial Chamber VI , 7 November 2019. At this writing, both judgments are on appeal.

${ }^{50}$ ICC, Prosecutor v. Lubanga, Judgment on the appeals against Trial Chamber II's 'Decision Setting the Size of the Reparations Award for which Thomas Lubanga Dyilo is Liable', ICC-01/04-01/06-3466-Red, Appeals Chamber,18 July 2019, para. 37. On Lubanga, see also note 9 and accompanying text.

${ }^{51}$ Error! Main Document Only. ICC, Decision Pursuant to Article 15 of the Rome Statute on the Authorisation of an Investigation into the Situation in the People's Republic of Bangladesh/Republic of the Union of Myanmar, ICC01/19, Pre-Trial Chamber III, 4 November 2019, para. 29. 
commander who said he had been abducted into the armed group at age fourteen. ${ }^{52}$ In her opening statement Prosecutor Bensouda maintained that presumed status as a "perpetratorvictim" did not bar prosecution of the accused: "[H]aving suffered victimization in the past is not a justification, nor an excuse to victimise others," she said, adding that her office aimed to "prove what he did, what he said, and the impact of those deeds on his many victims". 53 The evidentiary phase concluded in December 2019, and the case now awaits verdict.

A persistent obstacle to securing accountability for crimes against and affecting children is related to the tendency to focus prosecutions on high-ranking officials. Several cases before the ICC have turned on whether judges concluded that the accused himself bore responsibility pursuant to one of the modes of individual criminal liability set out in the Rome Statute. A number of such prosecutions resulted in acquittal, at either the appellate or trial level. In one case, judges deemed the presence of armed and underaged child combatants to have been widespread, yet entered judgments of acquittal on the ground that there was insufficient proof of a link between their presence and the culpability of the accused. ${ }^{54}$ In another, a military commander was acquitted in an appellate judgment that rejected a Trial Chamber's conviction based on the doctrine of command responsibility. ${ }^{55}$ At times too, failures of proof have been attributed to concerns regarding reliability of evidence, particularly regarding younger witnesses;

\footnotetext{
52 Policy on Children, p. 12, para. 17, quoted text accompanying note 27.

53 ICC, "Statement of the Prosecutor of the International Criminal Court, Fatou Bensouda, at the opening of Trial in the case against Dominic Ongwen”, 6 December 2016. On this litigation, see ICC, “Ongwen Case: The Prosecutor v. Dominic Ongwen, ICC-02/04-01/15”. For a sociological analysis of the issues posed, see Carse Ramos, "Dominic Ongwen on Trial: Problematizing Definitional Boundaries and Exploring the Possibilities of Socialization”, in Mark A. Drumbl and Jastine C. Barrett (eds), Research Handbook on Child Soldiers, Cheltenham, UK, Edward Elgar Publishing, 2019, p. 374.

54 See ICC, Procureur c. Mathieu Ngudjolo, Jugement rendu en application de l'article 74 du Statut, ICC-01/04-02/12, ICC Trial Chamber II, 18 December 2012, and ICC, Procureur c. Germain Katanga, para. 1025, ICC-01/04-01/07, Jugement rendu en application de l'article 74 du Statut, ICC Trial Chamber II, 7 March 2014, analyzed in Amann, “Children”, pp. 263-266.

55 ICC, Prosecutor v. Bemba, Appeals Judgment, Case No. ICC-01/05-01/08, 8 June 2018; see Leila Nadya Sadat, International Decisions: Prosecutor v. Jean-Pierre Bemba Gombo”, American Journal of International Law, Vol. 113, No. 2, 2019, pp. 353-361.
} 
that fact presents a particular challenge for the implementation of a more comprehensive approach to prosecution of crimes against or affecting children.

Especially challenging, it must be said, is a change in geopolitical appetite for international criminal accountability. An example may be found in the narrative of the Prosecutor's 2017 request to open an investigation into conduct in Afghanistan, an ICC State party, by members of armed groups like the Taliban and of the armed forces of Afghanistan and the United States. ${ }^{56}$ Among the actions alleged, in addition to the criminal recruitment of children, were attacks on schools and hospitals, gendered violence against girls and crimes against child detainees. ${ }^{57}$ While the request was pending, in April 2019, the United States retaliated against the inquiry by revoking the Prosecutor's US visa; within weeks, a Pre-Trial Chamber rejected the request based on a novel application of the Rome Statute's interests-ofjustice provision. ${ }^{58}$ Under judicial deliberation at the time of this writing is an appeal of that rejection, which set back efforts to depict a range of children's experiences in conflict.

Such reverses underscore that international criminal justice alone cannot secure accountability for crimes against or affecting children, let alone fully prevent those crimes. The success of international criminal justice depends on support from States, other international organizations, and civil society. The Policy on Children of the ICC Office of the Prosecutor has a role to play among these entities; as Bensouda put it in 2016: "I hope that this Policy will also serve as a useful reference for national authorities, civil society and other actors in their endeavours to address crimes against and affecting children, and to improve the experience of children in judicial processes". 59

${ }^{56}$ ICC, Situation in Afghanistan, Public redacted version of "Request for authorisation of an investigation pursuant to article 15", ICC-02/17-7-Conf-Exp, 20 November 2017 (Afghanistan request).

${ }^{57}$ Afghanistan request, p. 48, para. 87; p. 82, para. 171; pp. 60-62, paras. 116-121; pp. 72-75, paras. 145-153; p. 79, para. 165 ; p. 167 , para. 343 ; p. 173, para. 358.

${ }^{58}$ ICC, Decision Pursuant to Article 15 of the Rome Statute on the Authorisation of an Investigation into the Situation in the Islamic Republic of Afghanistan, ICC-02/17-33, Pre-Trial Chamber II, 12 April 2019; see Marlise Simons and Megan Specia, “U.S. Revokes Visa of Chief Prosecutor at I.C.C.”, New York Times, 6 April 2019, p. A4.

${ }^{59}$ Error! Main Document Only. Fatou Bensouda, "Welcome and Opening Remarks, Official Launch of the Office of the Prosecutor's Policy on Children", 16 November 2016, available at: https://www.icc-cpi.int/iccdocs/otp/ICCProsecutorsSpeechatChildrenSlaunchevent.pdf. See also Valerie Oosterveld, "The ICC Policy Paper on Sexual and 
States, international organizations and civil society also must work for prevention in spheres other than the ICC, and by means other than criminal prosecution. Salutary recent events in this respect include: the 2019 filing by Gambia of an International Court of Justice case alleging Myanmar's state responsibility for genocidal acts against Rohingya children and adults, ${ }^{60}$ the 2017 Inquiry into Protecting Children in Armed Conflict, chaired by UN Envoy Gordon Brown, which produced a 500-page exposition of pertinent legal instruments and jurisprudence and norms of international humanitarian law, human rights law, international criminal law, and customary international law; ${ }^{61}$ and, as well, a number of UN initiatives to combat the conflict-related detention of children. ${ }^{62}$ Commentators have a role to play; by way of example, it is unfortunate that, in its current form, a proposed treaty on crimes against humanity retains the 1998 Rome Statute definition of the crimes, and thus does not reflect newer understandings regarding children. ${ }^{63}$ The UN processes based on the Six Grave Violations, moreover, must continue to be strengthened. Civil society campaigns respecting attacks on education and child combatants, as well as recent attention to the effects on children of blast injuries, ${ }^{64}$ likewise merit continued endeavour. Through such interrelated initiatives, a path may

Gender-Based Crimes: A Crucial Step for International Criminal Law”, William \& Mary Journal of Race, Gender, and Social Justice, Vol. 24, No. 3, 2018, pp. 443-457, at p. 455 (describing predecessor policy paper as "a noteworthy addition to international guidance to states and others").

${ }^{60}$ ICJ, Application of the Convention on the Prevention and Punishment of the Crime of Genocide (The Gambia v. Myanmar)Error! Main Document Only., Application Instituting Proceedings and Request for the Indication of Provisional Measures, 11 November 2019, paras. 114, 116, available at: https://www.icj-cij.org/en/case/178.

${ }^{61}$ See Shaheed Fatima, Protecting Children in Armed Conflict, Hart, Oxford, 2018 (describing Inquiry at pp. 5-7, and setting out Inquiry's findings and conclusions).

${ }^{62}$ See UN Security Council Resolution 2427 (9 July 2018) (condemning such detention, as part of comprehensive resolution on children and armed conflict, and urging "non-judicial measures as alternatives to prosecution and detention"); Report of the Independent Expert Leading the United Nations Global Study on Children Deprived of Liberty, UN Doc. A/74/136, 11 July 2019, available at: https://undocs.org/en/A/74/136.

${ }^{63}$ See "Chapter IV. Crimes Against Humanity", in Report of the International Law Commission, Seventy-First Session (29 April-7 June and 8 July-9 August 2019), pp. 10-140, UN Doc. A/74/10, 2019, available at: http://legal.un.org/docs/ (setting out definition virtually identical to that in the Rome Statute, yet omitting, following advocacy by civil society, the statute's definition of "gender").

${ }^{64}$ See Save the Children, Blast Injuries: The Impact of Explosive Weapons on Children in Conflict, 2019, available 
be found to the prevention and punishment of the full array of wartime harms to children.

at: https://reliefweb.int/sites/reliefweb.int/files/resources/CH1325872.pdf. This report composed a part of a larger advocacy campaign by this century-old nongovernmental organization. See Save the Children, "Stop the War on Children", available at https://www.stopwaronchildren.org/. 